May 2007

\title{
Institutional Development, Financial Deepening and Economic Growth: Evidence from China
}

\author{
Iftekhar Hasan \\ Lally School of Management \\ Rensselaer Polytechnic Institute \\ and Bank of Finland \\ $1108^{\text {th }}$ Street, Troy, NY 12180 USA \\ hasan@rpi.edu \\ Paul Wachtel \\ Stern School of Business \\ New York University \\ 44West $4^{\text {th }}$ Street, New York, NY 10012 USA \\ pwachtel@stern.nyu.edu
}

Mingming Zhou

Lally School of Management

Rensselaer Polytechnic Institute

$1108^{\text {th }}$ Street, Troy, NY 12180 USA

zhoum@,rpi.edu

JEL Classifications: O16, P14, P16, O53

Keywords China, Institutional Development, Financial Deepening, Political Pluralism, Economic Growth 


\title{
Institutional Development, Financial Deepening and Economic Growth: Evidence from China
}

\author{
Iftekhar Hasan, Paul Wachtel and Mingming Zhou
}

\begin{abstract}
There have been profound changes in both political and economic institutions in China over the last twenty years. Moreover, the pace of transition has led to variation across the country in the level of development. In this paper, we use panel data for the Chinese provinces to study the role of legal institutions, financial deepening and political pluralism on growth rates. The most important institutional developments for a transition economy are the emergence and legalization of the market economy, the establishment of secure property rights, the growth of a private sector, the development of financial sector institutions and markets, and the liberalization of political institutions. We develop measures of these phenomena, which are used as explanatory variables in regression models to explain provincial GDP growth rates. Our evidence suggests that the development of financial markets, legal environment, awareness of property rights and political pluralism are associated with stronger growth.
\end{abstract}




\section{Introduction}

The late twentieth century witnessed the transformation of numerous centrally planned economies around the world to market systems. Many of these transitions were characterized by a "Big Bang" (Hoff and Stiglitz, 2004) that combined economic liberalization with massive forces of democratization and rapid privatization. Democratization and economic liberalization generally accelerate growth with the establishment of market oriented institutions, which in turn determine other economic policies (Persson and Tabellini, 2006). Economists have long been interested in the role of institutions and financial markets in explaining economic transitions and growth. Rajan and Zingales (1998) argue that financial development facilitates economic growth by reducing the costs of external finance to firms; their empirical evidence from a cross-country study supports this rationale. Guiso, Sapienza and Zingales (2004) examine the effects of differences in local financial development that can explain the spread of entrepreneurship and economic growth. La Porta, Lopez-de-Silanes, Shleifer and Vishny $(1997,1998,2000)$ study the relationship between law and finance, and consequently economic development, and highlight the importance of legal institutions.

China has followed a quite different path where economic reform and transition to a market economy occurred without democratization, liberalization proceeded only incrementally and privatization was delayed until almost two decades after the initiation of reforms. The development of China has followed an incremental and experimental approach to reform that has resulted in high and stable growth rates for over three decades (Prasad and Rajan, 2006). This remarkable growth performance was accompanied by a relatively undeveloped legal and financial system, which makes China a puzzle. According to Allen, Qian and Qian (2005), China seems like "a counterexample to the findings in law, institutions, finance and economic growth literatures." They document the poor legal protection of minority interests and outside investors and the dominant role of the state public sectors. Cull and $\mathrm{Xu}(2005)$ use a survey of managers to find that expropriation risk plays a role in Chinese firms' reinvestment decisions. 
These prior studies have examined the unique features of Chinese law, institutions and financial system, and their role in China's economic growth. However, none of these studies relates China's regional economic growth to the differences across the vast country in the timing and extent of institutional development. Out intent is to see whether the economic performance of China can be ascribed, at least partially, to this evolution of the country's legal, economic and political institutions and its financial markets.

We use a panel of data from the Chinese provinces to study the relationship between measures of the development of legal and political institutions and indicators of financial market development, and economic growth. We will exploit the regional differences in the timing and extent of these developments to demonstrate the impact on economic growth. Based on a sample of 31 Chinese provinces for the period 1986-2003, our empirical results indicate that those regions with greater rule of law, more property rights awareness and more political pluralism also have stronger growth. We believe these findings further our understanding of the "Chinese economic miracle," and consequently add to the growing literature relating to law, institutions, finance and economic growth.

The rest of the paper proceeds as follows. Section I provides a description of institutional reforms and financial sector development in China over the last two decades. Section II reviews the relevant literature. Section III describes our data and the various measures we employ for institutional development. In Section IV, we present our results and examine the relationship between institutional development and growth in China. Concluding remarks are found in Section V.

\section{Decentralization, institutional reform and financial sector development}

The transition from planned to market economy necessitates the establishment of an almost entirely new set of institutions. However, the desire of the Chinese Communist Party to retain a monopoly on political power inhibits the development of legal institutions and the evolution of local governmental authorities. Nevertheless, there have been dramatic ideological shifts in China already that have resulted in the 
gradual development of legal institutions, the decentralization of political institutions, rapid growth of the private sector and the development of financial markets. We will briefly describe the institutional developments in China that are likely to have effected economic growth

Banking reform. Credit markets in China are relatively large by international standards; the assets of deposit money banks are a larger share of GDP than in the US. However, credit to the private sector is a much smaller share of GDP than in most other countries. Reform of the financial system began in the early 1990s when the central government decided to separate the policy banks from commercial banks. Subsequent developments included the transformation of urban credit cooperatives into commercial banks (1996-1998), granting limited licenses to some foreign banks and granting licenses to non-state commercial banks and introducing standard accounting and prudential norms. Despite the reforms, serious problems in the banking sector persisted such as non-performing loans (NPLs) and extensive corruption (Chen and Feng 2000). However, many additional changes were introduced after China's entry into the WTO in 2001. These include further liberalization of interest rates, fewer restrictions on ownership and increased operational freedom. The most recent developments include partial privatization with shares sold in the market and minority foreign ownership stakes (see Berger, Hasan, and Zhou (2007) for more background information of Chinese banking sector).

Development of capital market. The establishment of the Shanghai Stock Exchange in 1990 and the Shenzhen Stock Exchange in 1991 was initially aimed at promoting the reform of state owned enterprises (SOEs). Soon thereafter, tens of thousands of SOEs sought permission to restructure into shareholding companies. In the early 1990s, local leaders retained significant influence over the listing process and the enforcement of secondary market regulation, but in the late 1990s, the central regulatory authority was able to consolidate its influence. The stock market regained the confidence of public investors and has enjoyed rapid expansion since then.

Corporate bonds markets lagged behind the development of the equity market. Although bonds were first issued in 1986, outstanding corporate bond issues in 1999 
were only about one-half of one percent of GDP (People's Daily, Sept. 1, 2000). The corporate bond market began to expand after 2000 when new rules governing issuance were implemented. Local firms, besides the giant SOEs, are also encouraged to issue corporate bonds and market forces increasingly determine the spread on bonds.

Growth of the private sector. An important outcome of the market-oriented reforms in China is the emergence of a significant private sector, which now accounts for about a third of GDP (IFC 2000). The development of the private sector was part of the unique Chinese "dual-track" approach to reform. Private enterprises first took hold in rural areas and in the 1980s larger private enterprises began to emerge although they were not officially recognized until 1988. In the 1990s, government policies began to encourage the transformation of SOEs and collectives into private enterprises. Private enterprises developed rapidly and a constitutional amendment in 1999 formally recognized this shift, thereby allowing the private sector to emerge from the shadows.

The growth of private sector has mitigated the social costs of SOE reforms and led to China's impressive share in world exports. Despite the contributions of the private sector to the economy, it is poorly served by the formal financial markets, as only a very small portion of bank credit goes to private firms and only a small share of listed firms are fully private. As a result, private firms rely heavily on informal financial channels and self-financing.

Evolving legal environment. The development of the modern Chinese legal system starts after the Cultural Revolution when members of the legal profession were rehabilitated and a new state constitution that emphasized the rule of law was enacted. In the 1990s, legal reform became a government priority and legislation designed to modernize and professionalize the nation's lawyers, judges, and prisons was enacted. For example, the 1994 Administrative Procedure Law allows citizens to sue officials for abuse of authority or malfeasance. There are more than 800,000 mediation 
committees, consisting of informed citizens, that resolve about $90 \%$ of China's civil disputes and some minor criminal cases. ${ }^{1}$

As part of its economic and legal reforms, China adopted a patent law to protect foreign patents in 1984 . In the late 1980s, regulations regarding shareholding enabled enterprises to define property rights and separate collective and private enterprise shares. The 1994 Company Law improved property rights by establishing the firm as a legal entity that owns assets.

Further steps to assuring rights to private property have been taken in recent years. . One notable feature of the evolution of the legal environment is that the laws regarding property rights were locally enacted, following national legislation, and thus the implementation differed across regions (Krug and Hendrischke 2001).

Development of the political environment. While China is still regarded as a communist state, a simple categorization is an inadequate characterization. China is slowly becoming a capitalist economic system, although its political regime remains largely authoritarian and extensive public ownership remains. The dominant role of the Communist Party of China (CPC) is guaranteed by the country's constitution. However, since the early 1990s, the party has been subject to the authority of the state and the constitution.

The National People's Congress (NPC) is the highest legislative body in China, and its functions include electing the President of China and approving the work of top officials. Although the membership of the NPC is still largely determined by the CPC, since the early 1990 's, it has moved away from its previous role as a symbolic but powerless rubber-stamp legislature, and has become a forum for debating ideas and for achieving consensus over a wide range of issues.

Delegates to the NPC are elected by the provincial people's congresses for a term of five years. The provincial congresses are in turn elected by lower level congresses, with a series of layers that ends with popularly elected low level congresses. . This system of layered indirect elections has the consequence that the

\footnotetext{
1 The statistics are provided by U.S. Department of State, Bureau of East Asian and Pacific Affairs, Electronic Information and Publications Office, Background Note: China, January 2007.
} 
Communist Party of China maintains effective control over delegate selection although there is considerable amount of decentralization involving local Communist politics. In recent years, approximately one third of the seats are informally reserved for non-party members, which include professional experts and members of minority political parties.

This brief summary of the major changes in economic and political institutions in China shows two things. First, the reform process has already touched on a broad range of economic, political and social institutions. Second, the uneven pace of reform leads to considerable variation across the country and over time in institutional development. In this paper, we try to exploit these differences over time and place to better understand the determinants of growth.

\section{Literature Review}

Since our review of institutional reform in China has emphasized three facets of such development - legal, financial and political institutions, - we focus here on the literature that links these issues to growth and China in particular. Generally, the link between institutional development and economic growth has gained increasing interest among researchers in recent decades. (Demirguc-Kunt and Maksimovic, 1998; La Porta, Lopez-de-Silanes, Shleifer and Vishny, 1998; Rajan and Zingales, 1998; Wachtel, 2001). To begin, well-defined property rights are a cornerstone for private sector development and growth. Furthermore, the protection of property rights facilitates the development of financial markets. Finally, well-functioning and flexible financial markets allow entrepreneurs to embrace economic opportunities and respond to technology shocks (Baumol, 1990).

Using data on Chinese entrepreneurs, Djankov, Qian, Roland and Zhuravskaya (2006) highlighted the importance of legal and economic institutions in fostering entrepreneurship. Jonhson, McMillan and Woodruff (2002) examine the relative importance of property rights and external finance in several transition countries. They find property rights to be overwhelmingly important. Acemoglu and Johnson (2003) separate proxies for the security of property rights into two groups, i.e., those 
measuring the risk of expropriation and those measuring the ease and reliability of contract enforcement, and their cross-country results suggest that risk of expropriation is the more severe impediment to economic development. Similarly Cull and $\mathrm{Xu}$ (2005) use Chinese firm level data and show that at China's current stage of development, expropriation risk, contract enforcement, access to finance, and ownership structure all appear to matter for Chinese firms' reinvestment decisions.

Political institutions, another component of the institutional framework, also exert an important influence on economic growth. In a transition economy, an improving democracy may have significant effect on political and economic conditions of a country (Rodrik and Wacziarg, 2006). Researchers often used the degree of democracy or level of corruption to capture the contribution of political institutions. Corruption, which is a signal of the quality of political institutions, imposes substantial economic costs, particularly in less developed economies (Shleifer and Vishny, 1993). Empirical evidence from cross-country or cross-region studies (Mauro, 1995; Hall and Charles, 1999) confirms that corruption negatively affects aggregate outcomes such as growth and investment rates.

An aspect of political institutional development that is beginning to attract more attention is the link between political pluralism and economic liberalization and development. In democratic politics, pluralism is a guiding principle that permits the coexistence of different interests. Political pluralism plays a role in economic growth because there may be an intrinsic connection between the dispersal of political power inherent in the competitive market economy and political pluralism (Rodrik and Wacziarg, 2006). Representativeness, accountability and transparency are essential aspects of well-functioning political institutions and since political institutions determine economic policies, one would expect that economic liberalization should be positively related to the degree of political pluralism in the country or region.

There are some other studies that examine the disparities among China's different provinces (Borensztein and Ostry, 1996; Liu and Li, 2001), but very few of them make efforts to incorporate the role of institutions. However, there are a few studies that look at province-level data on financial sector development and the 
private sector. Chen and Feng (2000) find that growth of private and semi-private enterprises leads to an increase in economic growth while the presence of SOEs reduces growth rates among the provinces based on their sample 29 Chinese provinces from 1978 through 1989. Aziz and Duenwald (2002) and Boyreau-Debray (2003) both find little influence of financial sector depth at the provincial level on growth primarily because little credit growth in the 1990s went to the private sector. More recently, Liang (2005) and Hao (2006) find evidence that financial depth and the reduced role of government influence provincial growth rates.. In addition, Biggeri (2003) uses provincial level data for the period 1986 to 2001 and finds that the level of aggregate output in each province is negatively influenced by the presence of state owned enterprises, a proxy for the extent of marketization of the economy. These early studies of inter-provincial differences in growth indicate that our effort to measure institutional development with recent data is clearly warranted.

\section{Data and Methodology}

Empirical research using cross-country data has provided much insight on the role of institutions in promoting economic growth (King and Levine, 1993; Knack and Keefer, 1995; Rousseau and Wachtel, 2000). However, cross-country studies are sometimes faulted for being unable to distinguish between the proximate determinants of growth and country specific idiosyncrasies. Although it might be tempting to examine Chinese experiences by making comparisons with transition experiences in Europe and the former Soviet Union, the unique transition path chosen by China would make this approach unreliable.

The use of sub-national data has major advantages over cross-country studies in addressing these issues. The data comparability issue, for example, is less serious within a country than across countries. While the comparison of institutional and political characteristics across countries can be difficult due to the diversity in historical experiences, cultural norms and institutional contexts, sub-national data can control for such contexts and focus on specific aspects of the institutional and political 
system. Our sample consists of a panel for 31 provinces $^{2}$ in Mainland China with annual data for 1986-2002.

Our dependent variable, growth, is the growth rate of real annual per capita GDP in the province. ${ }^{3}$ GDP and other macroeconomic data for the provinces were collected from China Economic Information Network Database. The original sources of these data are the annual issues of the Statistics Yearbook of China.

A major challenge in this paper was to find data that adequately measure or proxy the institutional developments of described in section I. In some instances direct measures of institutional development can be obtained while in other instances the available data provide only imperfect proxies. We will begin with the financial institutions for which direct measures are obtainable and widely used in growth studies. We will then proceed to the legal and political institutions for which proxies provide indirect but adequate representations.

For the development of the financial sector, we use two measures of financial depth, one based on banks alone and the other on non-bank sources of private sector financing:

(1) The ratio of total bank loans to GDP measures banking sector depth. Bank loans data are obtained from the annual issues of the Almanac of China's Finance and Banking (ACFB). Prior to 1989 data are only available for state-owned bank loans. ${ }^{4}$ The two series are very similar in the 1980s and early 1990s, because the state-owned banks were dominating the banking sector, occupying more than $97 \%$ of the total banking assets. The data are linked using the ratio of the series in 1994 (the year prior to major financial reforms).

\footnotetext{
2 The 31 provinces, including four municipalities with the same level of authority as the provinces are Anhui, Beijing, Chongqing, Fujian, Gansu, Guangdong, Guangxi, Guizhou, Hainan, Hebei, Heilongjiang, Henan, Hubei, Hunan, Jiangsu, Jiangxi, Jilin, Liaoning, Neimenggu (Inner Mongolia), Ningxia, Qinghai, Shanxi, Shandong, Shanghai, Shanxi, Sichuan, Tianjing, Xinjiang, Xizhang, Yunnan, Zhejiang.

3 The variable is defined as the change in the log of real per capita GDP.

4 According to ACFB, bank loans are defined as "the sum of loans by central banks, policy banks, the big four state-owned banks, as well as other commercial banks", while the state-owned bank loans are defined as "the sum of loans by central banks, policy banks, and Big Four state-owned banks".
} 
(2) The ratio of equity and non-financial corporate debt (long-term and short-term) issuance to GDP is a measure on non-bank financial market activity. The issuance is for firms incorporated in the province. In the sense that the issuance of equity and corporate bonds represents the activities of the capital markets, this ratio also captures the degree of development of financial institutions such as investment banks, accounting firms, supervisory bodies, etc. The equity issuance data are collected by summarizing the equity issuance data from both exchanges in China, based on the annual issues of the Statistics Yearbooks of Shanghai Stock Exchange, and the Statistical Yearbooks of Shenzhen Stock Exchange. Equity issuance is defined as the proceeds received by listed firms raised from IPOs, SEOs, and rights issues. Data on corporate bonds issuance are collected from the ACFB and are available until 1999. After that data are obtained from the annual issues of the provincial yearbooks, and for those missing corporate bond issuance data, they are extrapolated for each province based on the growth in national bond issuance.

We turn now to variables that represent legal and related institutional developments.

(3) The size of the private sector in a province is measured by the ratio of private sector total fixed investment to overall total fixed investment. This measure reflects the relative size of the private sector, and also, as suggested by $\mathrm{Cull}$ and $\mathrm{Xu}$ (2005), the extent of property rights protection. The data are from the China Economic Information Network Database and the original source of data on total capital formation is the China National Statistics Bureau (CNSB).

(4) The rule of law is always difficult to measure; we take the presence of legal professionals as an indicator. Specifically, our variable is the number of lawyers per 10,000 people. This ratio should capture the degree of development of public integrity mechanisms, which promote public accountability and limit corruption. The data are collected from the Statistics Yearbook of China's Legislation and the annual issues of the Statistics Yearbooks of each province, which provide data for 1990, 1995 and 2000-2002). Additional information was collected from other web based resources, such as the China Law of Lawyering (china-lawyering.com), China 
Lawyers Investigation website (www.007cn.cn), and China Lawyers website (www.chineselawyer.com.cn). These websites provided additional data on the number of lawyers on a province or city basis since the 1990s. Missing data are interpolated based on nation wide growth in the number of lawyers. The population data are obtained from the National Bureau of Statistics of China. China conducted population censuses in 1982, 1990 and 2000 and 'semi censuses' in 1987 and 1995. In addition, annual population surveys have been conducted since 1983 .

(5) Our proxy for the awareness of property rights is the ratio of the number of domestic trademark applications to the number of firms. This ratio should capture both awareness of property rights and the degree of development of secure property rights-associated institutions in each province. The domestic trademark application data were collected from the annual issues of Almanac of China's Property Rights and the Yearbook of China's Industrial and Commercial Administrative Statistics (which provide data starting in 1998), annual provincial yearbooks, and the government-sponsored trademark website, China Trademark Online. Missing data are backcasted using the national data and the proportions of applications in the province in 1998.

(6) Although political pluralism is in its rudimentary stages in China, the extent to which non-Communist Party members participate in the People's Congresses is an indicator of its strength. Our variable is the proportion of non-party members in the provincial People's Congress relative to the proportion in the National People's Congress. ${ }^{5}$ If the provincial proportion of non-Communist Party members is

5 The proportion of non-Communist Party members in the People's Congress at the national level is not just average of the ratios of all provinces in China; instead, it is the proportion of non party member from the National People's Congress. National People's Congress members are elected from the Congress members at the province level. This national measure is an excellent indicator of the overall political environment in the whole country, in the sense that just before each once-in-5-year election year, the national-level Standing Committee of the People's Congress will issue a recommendation of membership structure of the to-be-elected new Congress members, both applied to national People's Congress, and various sub-level Congresses. Such recommendations have binding powers because the ex-post membership structure are required to be reasonably close to the recommended structures of various membership. 
higher than the national benchmark at that time, then the province arguably has a more relaxed or pluralistic political environment.

The data are collected from the regional People's Congress Yearbooks of each province in China that are compiled intermittently. Even though yearbooks are published for most provinces, the information on membership structure is not always available. Another data source for the People's Congress data was the Examination and Approval Reporting Document issued by the Examination Committee of People's Congress which addresses whether the newly-elected People's Congress members of the provinces have conformed to the recommended benchmarks from the national-level People's Congress. In such examination reports, there is often a declaration of the number and proportions of members who represent various classes or parties. Still, there are six provinces for which we cannot find any information of the membership structures of the People's Congress, and those missing data are estimated judgmentally by using data from neighboring provinces with similar political characteristics. Since the People's Congresses are re-elected every five years, the proportions of non-Communists in the Congress hold constant for every five years, roughly at the intervals of 1983-1987, 1988-1992, 1993-1997, and 1998-2002.

(7) Finally, we include three control variables that are commonly found in growth rate studies. First, the log of real initial (or lagged) GDP per capita will provide evidence of any convergence effects. Second, a secondary school enrollment ratio controls for the influence of human capital investments on growth. Our variable is the ratio of total number of students enrolled in junior secondary schools to the number of graduates from the primary schools. Nine years of basic education (six in elementary and three in junior secondary schools) have been compulsory since 1986 ., Our data for secondary school enrollment rates are from the Comprehensive Statistical Data and Materials on 50 Years of New China (for 1986-1998), and for later years (1999-2002), the China Statistical Yearbooks. Third, the ratio of exports to GDP is a measure of openness of the local economy. 
Descriptive statistics and variable names are shown in Table 1 and Table 2 presents the correlation matrix of the variables. The mean real GDP growth rate is 7.0 percent and the standard deviation is almost as large. The explanatory variables also show a great deal of variation. There range indicates that there are outlier observations though no effort was made to exclude such observations other than to include fixed effects for provinces in some regressions. Interestingly, the simple correlations with the growth rate of GDP are all modest. The level of GDP is highly correlated with the schooling, openness and the institutional variables. Interestingly, the correlation of the level of GDP is not as highly correlated with the financial variables or the size of the public sector.

Our model builds on the approach to growth equations introduced by Barro and Levine (1991). The baseline equation includes the convergence effect (log of initial real GDP), the human capital investment variable (schooling) and the export ratio (openness). We will show that the baseline regression provides a reasonable framework for analyzing growth in China. We then add measures of financial sector development, institutional development and political pluralism to the baseline regression. More specifically, we use the contemporary base model and financial variables instead of the lagged terms (except for 'log of initial per capita real GDP') in the models, to be consistent with the growth theories which stress the potential connection between growth and the contemporaneous provision of financial services, and to avoid efficiency (informational) loss discussed by Levine, Loayza and Beck (2000).

We start with OLS regressions that are shown in Table 3 with robust standard errors. It is well known that OLS estimates are biased and inconsistent when there are dynamic effects and simultaneities in the specification. To account for these effects the recent literature (e.g., Levine et al., 2000, Beck et al., 2000) has employed the Generalized Method of Moments (GMM) techniques developed by Arellano and Bond and others for panel estimation and results with this technique are found in Tables 4 and 5. 
The Arellano Bond GMM technique is specifically designed to address the econometric problems induced by unobserved group-specific effects and joint endogeneity of the explanatory variables in lagged-dependent-variable models, such as growth regressions. Similar to Levine et al. (2000), we employ an augmented GMM procedure outlined in Arellano and Bover (1995) and developed in Blundell and Bond (1998), which combines the regression in differences with the regression in levels (see Bond 2002). In the Blundell and Bond GMM estimator, the instruments for the regression in levels are the lagged differences of the corresponding variables, and the instruments for the regression in differences are the lagged levels. ${ }^{6}$ These are appropriate instruments under the additional assumption: that there is no correlation between the differences of these variables and the country-specific effects, while correlation between levels of the right-hand side variables and the country-specific effect is allowed. There are two tests to test the validity of the instruments, as suggested by Arellano and Bover (1995) and Blundell and Bond (1998). The first is the Sargan test or Hansen test of over-identifying restrictions, which tests the overall validity of the instruments by analyzing the sample analog of the moment conditions used in the estimation process. ${ }^{7}$ The second test is the autoregressive (AR) test, which examines the hypothesis that the error term $\varepsilon_{i, t}$ is not serially correlated in both the difference regression and the system difference-level regression. By construction, the differenced error term is allowed to be first-order serially correlated, but the second-order serially correlation of error term will violate the assumption of GMM procedure.

Table 4 presents the equations with annual data estimated with the Blundell and Bond dynamic panel-data estimation technique, i.e., two-step system GMM

\footnotetext{
${ }^{6}$ More specifically, we use the two-step GMM instead of one-step because two-step is asymptotically more efficient, meanwhile we also compensate the potentially downward biased two-step standard errors by making a finite-sample correction to the two-step covariance matrix derived by Windmeijer (2005).

${ }^{7}$ As for the over-identifying restrictions, we conduct Hansen test instead of Sargan test, because the Sargan statistic is not robust to heteroskedasticity or autocorrelation while Hansen statistic, which is the minimized value of the two-step GMM criterion function, is robust.
} 
estimations. We treat all of the financial and institutional variables as endogenous and the baseline variables as exogenous. As described above, the instruments for the regression in levels are the lagged differences of the corresponding variables, and the instruments for the regression in differences are the lagged levels. In Table 4 we also report Wald Chi-square test statistic, P-value of Hansen test, and P-value of AR(1) and AR(2) tests. In all instances, the P-values of Hansen test and AR(2) test are larger than 0.05 , which indicates failure to reject the null hypotheses of over-identification and second-order serial correlation of error terms. In other words, the specification tests support the validity of the instruments. This supports the interpretation of the estimated coefficients as being free from endogeneity bias.

Another approach to the endogeneity problems commonly found in the growth literature is to use multi-year average growth rate as the dependent variable and to use initial year values for all the independent variables. For example, Levine, Loayza and Beck (2000) use non-overlapping five-year average data in their GMM specifications. Similarly, we report the GMM estimations based on three-year average growth rates in Table 5. ${ }^{8}$ These regressions satisfy the specification tests. There is no evidence of second order serial correlation and the regressions pass the Hansen specification test.

\section{Results and Interpretation}

Each of the regression tables shows the same model specifications. Absolute values of t-statistics are reported in parentheses in all the regression tables and *,**, *** indicate significance at the $10 \%, 5 \%$ and $1 \%$ levels respectively. The first equation reports the baseline model - regressions that only include the log of lagged real GDP per capita, the secondary school enrollment ratio and openness. The second equation shows the baseline growth model augmented by the two measures of financial sector development. Similarly, equation three introduces the legal

\footnotetext{
${ }^{8}$ Our panel consists of data for 31 provinces (including 4 municipalities) over the period 1986-2003, so there are six non-overlapping periods (1986-1988, 1989-1991,1992-1994,1995-1997,1998-2000, 2001-2002).
} 
institutions variables. Equation four presents the growth model augmented by both the financial and institutional variables. Equations six to nine introduce the political pluralism variable, and show the robustness of the results to some changes in specification.

The broad picture presented by the results is consistent with our expectations. Although, coefficient estimates and confidence levels vary from equation to equation and across tables, the overall picture is supportive of our hypotheses. The discussion that follow will be based on all three estimation approaches: OLS in Table 3, annual system GMM in Table 4, and three-year average system GMM in Table 5.

To begin the baseline regression provides some evidence of a convergence effect. In the OLS and annual system GMM estimations,, the convergence effect is mostly insignificant, while in the three-year average system GMM it is significant and in line with expectations. The effect of the secondary school enrolment rate variable on growth is consistently positive and significant in all equations. The openness variable is positive and significant in the three-year average system GMM but not with the OLS and annual system GMM estimates. Overall, the baseline variables perform better in the three-year average GMM models in Table 5 than in the OLS regressions in Table 3 and annual system GMM estimates in Table 4.

Turning to coefficients on the measures of financial sector depth the coefficients on bank loans to GDP and capital market activity to GDP are often of opposite sign. The bank depth variable is usually negative which is the opposite sign of what is expected, while the capital market depth variable is usually significant and positive. The bank depth coefficients are puzzling because this variable is widely used in cross-country studies to demonstrate the relationship between financial depth and growth with results that are robust. However, in this instance there might be a good reason why it bank lending may not have a positive influence on growth. That is, Chinese bank loans for most of our period were predominantly government directed and granted to inefficient state owned or related enterprises rather than the more efficient private sector. Biggeri (2003) shows that the output level in each province is negatively influenced by the presence of SOEs. In addition, our evidence of 
non-significance or even negative effect of bank loans on growth is largely consistent with earlier studies on China, such as Aziz and Duenwald (2002), Boyreau-Bebray (2003), which also use province data. Hao (2006) finds a similar negative effect of loans from state owned banks on growth.

On the other hand, the capital market depth variable reflects private sector activity and therefore might be more relevant in promoting the real growth in the Chinese context, and the impact of capital market depth on growth implied by our results is fairly large. The OLS regressions (Table 3) and annual system GMM (Table 4) suggest that the coefficient on the capital market depth is around 0.4 to 0.6. suggesting that one percentage point increase of the variable will increase the growth rate by 0.4 to 0.6 percent points. Now, consider an increase of the variable by one standard deviation (0.022 from Table 1). Such an increase in the capital market depth by 2.2 percent points increases the growth rate by 0.8 percentage points $(0.022$ $\mathrm{x}$ 0.4). With the three-year average system GMM estimates, the capital market ratio effect decreases to the range of 0.2 to 0.4 , but still large compared with other explanatory variables.

The presence of private sector has a strong and significant positive effect on growth, which is consistent with the existing growth literature. If the private sector investment ratio increases by one standard deviation, i.e., 0.154 (the sample mean is $0.374)$ then the growth rate would go up by about 1.5 percentage points $(0.154 \times 0.1)$.

The two measures of legal development - property rights awareness (trademark applications) and rule of law (lawyers) - have a simple correlation of 0.61 . Therefore, it is not surprising that the coefficients are sensitive to what is included in the equation and the estimation procedure used. Consider equation 4 in Table 4, which includes all the institutional and baseline variables but omits the political pluralism measures. A one standard deviation increase in either the rule of law measure or the property rights measure would lead to an increase in the growth rate of less about 1.1 percentage points $(0.69 \times 0.016)$. The magnitudes of these results are just suggestive since the coefficient estimates are a bit unstable. 
Finally, we introduce our measure of political pluralism, the relative presence of non-party members in the province People's Congress. The coefficients are positive and significant in almost all the estimations of OLS regressions, annual system GMM, and three-year average system GMM (see equation 6, 7, 8, 9). The coefficients in equation 6 of Table 4, for example, suggest that a one standard deviation (0.102) increase in relative pluralism is associated with as 0.6 percentage point increases in the growth rate..

In sum, our results show that after controlling for the province-specific effects, endogeneity and potential problems associated with weak instruments, the data suggest a strong, positive link between institutional development and economic growth in China.

Robustness tests. In order to be more confident in our results we preformed various robustness tests that will be summarized here. The robustness tests address two important issues. First, we investigate whether the use of interpolated data affects our results and second, we examine the influence on our results of atypical relationships between the central government and large municipalities or with provinces that are receiving policy preferences. In all instances examined, there are no changes to our conclusion.

As discussed in section III, the data for the full sample period includes several instances where the institutional variables were interpolated or estimated. In order to confirm the robustness of our results we re-estimated the models with interpolated or estimated data points excluded. First, we re-estimate the models with data for 1986-1999 only, which excludes the years for which 'Bond and equity issuance/GDP' data are projected. The results are essentially unchanged.

Second, we examined OLS estimates for 1990, 1995, and 2000-2003 the data points that are available for the 'Rule of law.' The interpolation of this variable for other years does not seem to affect our results. Third, we examine OLS and annual GMM estimates with data for 1998 - 2003 when the 'Property rights' measure is available. 
Fourth, data for 'relative pluralism' is missing for six provinces so we reestimated all the models with these provinces excluded. The results do not change when the provinces for which data was projected are excluded.

The central government tends to exercise much stronger control over four large municipalities (Beijing, Chongqing, Shanghai, Tianjin) than over the other provinces. Thus, we re-estimated the models without these four municipalities, and find that our results are robust as to whether we include the four municipalities in our sample or not. Finally, certain provinces have been, at times, beneficiaries of preferential policies such as favorable tax treatments, more economic autonomy and special economic zones. In order to take this preferential treatment into account we introduced a dummy variable for those province-year observations. The dummy is highly significant but the results are not otherwise changed. .

In sum, our panel results are robust to a variety of sensitivity analyses. Estimates with these robustness checks are available upon request from the authors.

\section{Conclusion}

Since China's economic success is virtually unparalleled in recent history, the transitional path that the country has followed may be unique as well. Thus it is important to see whether and how the specifically Chinese institutional structures transitions have exerted its effect on economic growth. In this paper, we review the institutional development in China since the start of reforms, and empirically examine the role of institutional development on economic growth, using cross-province sample. Our evidence, in general, indicates the strong role of institutional development in promoting economic growth.

We investigate three facets of institutional development: financial sector development, development of legal institutions and the development of legal institutions. The first facet is represented by measures of financial deepening which we find that only capital market depth has a strong influence on growth while the bank loans has non-significant or sometimes even negative impact on growth. Proxies for institutional development are harder to identify. A broad measure is 
simply the size of the private sector in the economy, which we find to have a strong influence on growth. It reflects the degree of protection of property rights, fairness of the judicial system, extent of allowance and tolerance of the local governments to the private sector and the extent of local entrepreneurship. Direct measures of legal development are harder to specify. We are able to identify proxies for the awareness of property rights and for the rule of law. Our measures are indicators of the extent to which institutions adequately protect property rights and provide an environment with mechanisms for public integrity mechanisms that promote accountability and limit corruption. There is modest support with our proxy measures for the influence of institutional development on growth. Finally, the third facet is the development of political institutions, which we measure by the degree of political pluralism. Here as well there are indications that the development of institutions leads to growth.

Taken as a whole, our evidence suggests that institutional development is strongly associated economic growth, based on the 31 Chinese province data for period 1986-2002. More specifically, those regions with more rule of law, more property rights awareness and protections, more innovation-friendly environment, more open environment for private and foreign investors, and more investment opportunities and more complete market institutions are associated with stronger growth. 


\section{References}

Acemoglu, D. and S. Johnson (2003). "Unbundling institutions," NBER Working Paper 9934.

Allen, F., J. Qian and M. Qian (2005). "Law, finance, and economic growth in China." Journal of Financial Economics 77(1): 57-116.

Arellano, M. and O. Bover (1995). "Another look at the instrument variable estimation of error-components models." Journal of Econometrics 68: 29-51.

Aziz, J. and C. Duenwald (2002). "Growth-financial intermediation nexus in China," IMF Working Paper 02/194, November.

Bai, C. E., J. Lu and Z. Tao (2006). "The Multitask Theory of State Enterprise Reform." American Economic Review 96(2): 353-357.

Barro, Robert J. and R. Levine (1991) "Economic growth in a Cross-Section of Countries." Quarterly Journal of Economics 106(2): 407-443.

Barro, R.J., X. Sala-i-martin, 1992. "Regional growth and migration: a Japan-United States comparison." Journal of the Japanese and International Economies 6, 312-46.

Baumol, W. J. (1990). "Entrepreneurship: Productive, Unproductive, and Destructive." The Journal of Political Economy 98(5): 893-921.

Berger, A. N., I. Hasan, and M. Zhou. (2007). Bank Ownership and Efficiency in China: What will Happen in the World's Largest Nation?

Biggeri, M. (2003). "Key Factors of Recent Chinese Provincial Economic Growth." Journal of Chinese Economic and Business Studies 1(2): 159-183.

Blejer, M. I. and G. Szapary (1990). "The Evolving Role of Tax Policy in China." Journal of Comparative Economics 14(3): 452-472.

Blundell, R. and S. Bond (1998). "Initial conditions and moment restrictions in dynamic panel data model." Journal of Econometrics 87: 115-143.

Bond, S. R. (2002). "Dynamic panel data models: a guide to micro data methods and practice." Portuguese Economic Journal 1: 141-162.

Borensztein, E. and J. D. Ostry (1996). "Accounting for China's Growth Performance." American Economic Review 86: 224-228. 
Boyreau-Debray, G. (2003). "Financial intermediation and growth: Chinese style." Policy Research Working Paper 3027, World Bank.

Brandt, L. and X. Zhu (2000). "Redistribution in a Decentralized Economy: Growth and Inflation in China under Reform." Journal of Political Economy 108(2): 442.

Castro, R., G. L. Clementi and G. Macdonald (2004). "Investor Protection, Optimal Incentives, And Economic Growth." Quarterly Journal of Economics 119(3): 1131-1175.

Chen, B. and Y. Feng (2000). "Determinants of economic growth in China: Private enterprises, eduction, and openness." China Economic Review 11: 1-15.

Cull, R. and L. C. Xu (2005). "Institutions, ownership, and finance: The determinants of profit reinvestment among Chinese firms." Journal of Financial Economics 77(1): 117-146.

Dayal-Gulati, A. and A.M. Husain (2002). "Centripetal Forces in China's Economic Takeoff." IMF Staff Papers, 49.

Demirguc-Kunt, A. and V. Maksimovic (1998). "Law, finance and firm growth." Journal of Finance 53(6): 2107-2137.

Djankov, S., Y. Qian, G. Roland and E. Zhuravskaya (2006). "Who Are China's Entrepreneurs?" American Economic Review 96(2): 348-352.

Guiso, L., P. Sapienza and L. Zingales (2004). "Does Local Financial Development Matter?" Quarterly Journal of Economics 119(3): 929-969.

Hall, R. and J. Charles (1999). "Why do some countries produce so much more output per worker than others?" Quarterly Journal of Economics 114: 83-116.

Havrylchyk, O. (2005). "Foreign Direct Investment in China: reward or remedy?" unpublished.

Hao, C. (2006). "Development of financial intermediation and economic growth: The Chineses Experience," China Economic Review 17: 347-62.

Hoff, K. and J. E. Stiglitz (2004). "After the Big Bang? Obstacles to the Emergence of the Rule of Law in Post-Communist Societies." American Economic Review 94(3): 753-763.

Javorcik, B. S. (2004). "Does Foreign Direct Investment Increase the Productivity of Domestic Firms? In Searching of Spillovers Through Backward Linkages." American 
Economic Review 94(3): 605-627.

Johnson, S. J. McMillan and C. Woodruff (2002). "Property Rights and Finance," American Economic Review 92(5): 1335-50.

King, R. G. and R. Levine (1993). "Finance and growth: Schumpter might be right." Quarterly Journal of Economics 108(3): 717-737.

Knack, S. and P. Keefer (1995). "Institutions and Economic Performance: Cross-Country Testing Using Alternative Institutional Measures." Economics and Politics 7(3): 207-227.

Krug, B. and H. Hendrischke (2001). "China Incorporated: Property Right, Privatisation, and the Emergence of a Private Business Sector in China." ERIM Report Series ERS-2001-81-ORG.

International Finance Corporation (IFC), 2000, China's Emerging Private Enterprises: Prospects for the New Century.

La Porta, R., F. Lopez-de-Silanes, A. Shleifer and R. W. Vishny (1997). "Legal Determinants of External Finance." The Journal of Finance LII(3): 1131-1150.

La Porta, R., F. Lopez-de-Silanes, A. Shleifer and R. W. Vishny (1998). "Law and Finance." The Journal of Political Economy 106(6): 1113-1155.

La Porta, R., F. Lopez-de-Silanes, A. Shleifer and R. W. Vishny (2000). "Investor Protection and corporate governance." Journal of Financial Economics 58(1-2): 3-28.

Levine, R., N. Loayza and T. Beck (2000). "Financial Intermediation and Growth: Causality and Causes." Journal of Monetary Economics 46(1): 31-77.

Levine, R. and S. Zervos (1998). "Stock Markets, Banks, and Economic Growth." American Economic Review 88(3): 537-558.

Liang, Z. (2005). "Financial Development, Marekt Deregulation and Growth: Evidence from China." Journal of Chinese Economic and Business Studies 3(3), 247-62.

Liu, T. and K. Li (2001). "Impact of liberalization of financial resources in China's economic growth: evidence from the provinces." Journal of Aisian Econmics 12: $245-62$.

MacLeod, Calum, 2006, It looks almost democratic, but don't forget it's China, USA Today. 
Mauro, P. (1995). "Corruption and growth." Quarterly Journal of Economics 110(3): 681-712.

Persson, T. and G. Tabellini (2006). "Democracy and Development." American Economic Review 96(2): 319-324.

Prasad, E. S. and R. G. Rajan (2006). "Modernizing China's Growth Program." American Economic Review 96(2): 331-336.

Rajan, R. G. and L. Zingales (1998). "Financial Dependence and Growth." American Economic Review 88(3): 559-586.

Rodrik, D. and R. Wacziarg (2006). "Do Democratic Transition Produce Bad Economic Outcome?" American Economic Review 95(2): 50-55.

Rousseau, P. L. and P. Wachtel (2000). "Equity markets and growth: Cross country evidence on timing and outcomes, 1980-95." Journal of Banking and Finance 24: 1933-1957.

Rousseau, P. L. and S. Xiao (2006). "Banks. Stock Markets and China's 'Great Leap Forward,"

Shleifer, A. and R. Vishny (1993). "Corruption." Quarterly Journal of Economics 108(3): 599-617.

Wachtel, P. (2001). "Growth and Finance: What do we know and how do we know it?" International Finance 4: 335-362.

Windmeijer, F. 2005. "A finite sample correction for the variance of linear efficient two-step GMM estimators.” Journal of Econometrics 126, 25-51. 


\section{Table 1 Summary Statistics}

Table 1 presents summary statistics of the variables used in this paper. $\mathrm{N}$ refers to province-year observations for 31 provinces (including four municipalities) during sample period 1986-2003. Annual Growth Rate in per capita Real GDP is the change in the natural logarithm of real per capita GDP. Real per capita GDP is defined as the per capita GDP deflated to the base year of 1985. Exports to GDP is defined as the ratio of total exports to GDP. Secondary School Enrollment Ratio is the ratio of total number of students enrolled in secondary school to the number of graduates from primary school. Bank Loan to GDP is the sum of total bank loans (including loans by the central bank, policy banks, big four state-owned banks, and other commercial banks) to GDP. Equity and Debt Issuance to GDP is the ratio of all stock market equity and non-financial corporate debt (both long-term and short-term) issuance to GDP. Trademark Applications per Firm (Awareness of property rights) is the number of trademark applications per firm; it is our proxy for the awareness of property rights. Lawyers per 10,000 people (Rule of law) is defined as the number of lawyers per 10,000 people, and this is the proxy for rule of law. Ratio of Private Sector Capital Investment to Total (Private sector presence) is the ratio of private sector total fixed investment to overall total fixed investment. Relative Pluralism is defined as the proportion of non-Communist party members in the provincial People's Congress relative to the proportion in the National People's Congress.

\begin{tabular}{lccccc}
\hline Variable & $\mathbf{N}$ & Mean & SD & Min & Max \\
\hline Annual Growth Rate in per capita Real GDP & 516 & 0.070 & 0.062 & -0.174 & 0.217 \\
Initial Real per capita GDP, RMB & 516 & 1704.1 & 1441.9 & 420.0 & 12694.3 \\
Exports to GDP & 515 & 0.125 & 0.152 & 0.012 & 1.018 \\
Secondary School Enrollment Ratio & 517 & 0.853 & 0.119 & 0.396 & 1.000 \\
Bank Loans to GDP & 512 & 0.857 & 0.282 & 0.316 & 2.925 \\
Equity and Debt Issuance to GDP & 517 & 0.010 & 0.022 & 0.000 & 0.360 \\
Ratio of Private Sector Capital Investment & & & & & \\
to Total (Private sector presence) & 514 & 0.374 & 0.154 & 0.025 & 0.703 \\
Lawyers per 10,000 (Rule of law) & 516 & 0.672 & 0.694 & 0.102 & 7.446 \\
Trademark Applications per Firm & & & & & \\
(Awareness of property rights) & 513 & 0.418 & 0.584 & 0.002 & 5.013 \\
Relative Pluralism & 527 & 1.018 & 0.102 & 0.672 & 1.403 \\
\hline
\end{tabular}


Table 2 Correlation Matrix

Table 2 presents correlation coefficients and the associated Bonferroni-adjusted significance levels of each correlation coefficients (in the parentheses) The definitions of the variables are same as in Table $1 . *$ indicates significance levels of less than $5 \%$.

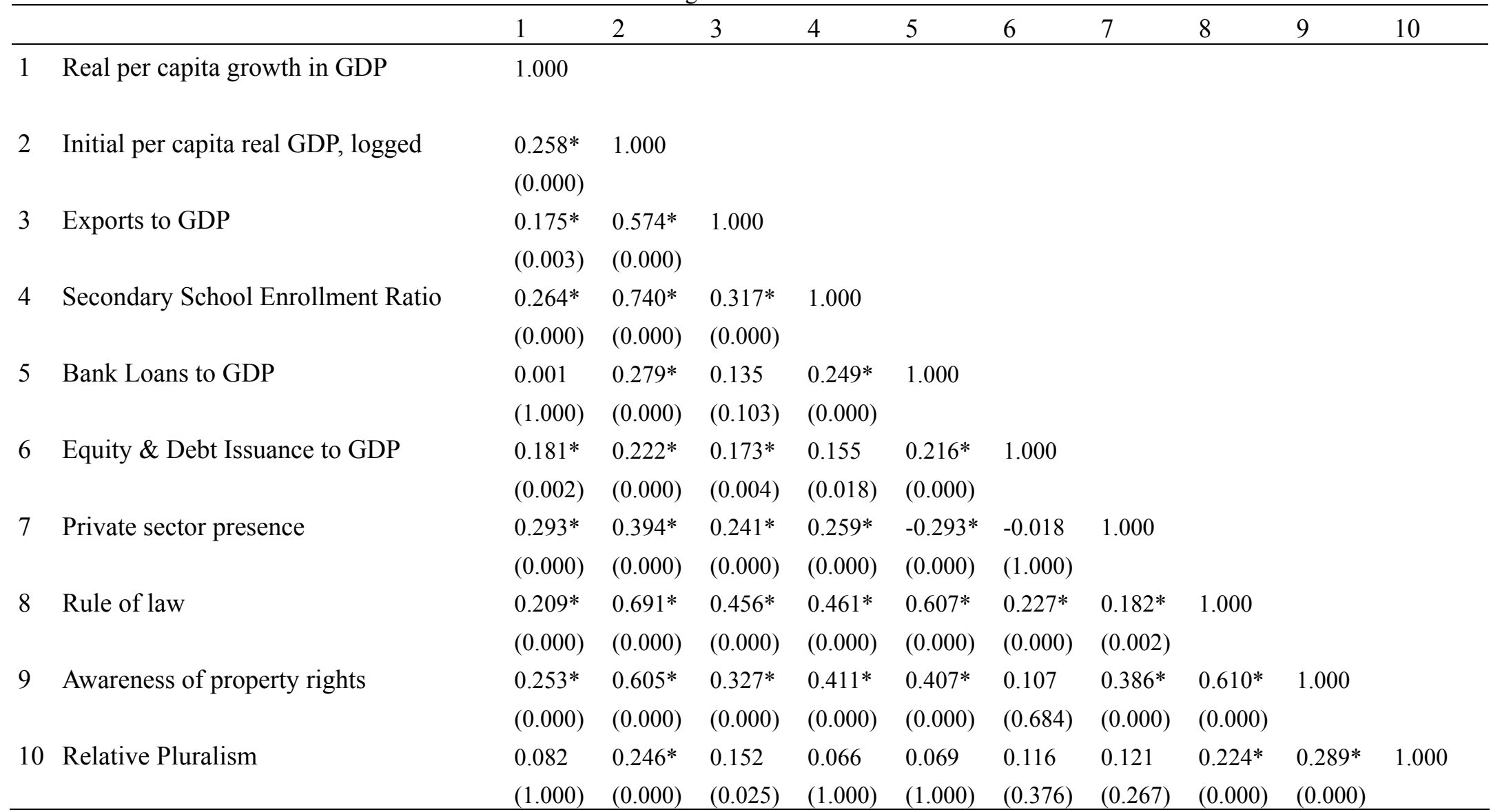




\section{Table 3 OLS Regressions of real per capita GDP growth, annual data}

Table 3 presents the OLS regressions of real per capita GDP growth based on the annual data at province level with White heteroskesdastic-consistent standard errors. The dependent variable is real per capita GDP growth, and we include log of initial per capita real GDP, export to GDP, and secondary school enrollment rate as the base variables in the regressions. Definitions of variables are same as in Table $1 . \mathrm{N}$ refers to number of observations included in the estimation. Absolute values of t-statistics of the coefficients of the independent variables are reported in parentheses. $*$, $* *$, $* * *$ indicate significance levels of $10 \%, 5 \%$, and $1 \%$, respectively.

\begin{tabular}{|c|c|c|c|c|c|c|c|c|c|}
\hline & 1 & 2 & 3 & 4 & 5 & 6 & 7 & 8 & 9 \\
\hline Constant & $\begin{array}{l}-0.074^{* *} \\
(2.23)\end{array}$ & $\begin{array}{l}-0.057^{*} \\
(1.70)\end{array}$ & $\begin{array}{l}0.024 \\
(0.51)\end{array}$ & $\begin{array}{l}0.083 * \\
(1.65)\end{array}$ & $\begin{array}{l}0.101^{*} \\
(1.93)\end{array}$ & $\begin{array}{l}-0.109 * * * \\
(3.33)\end{array}$ & $\begin{array}{l}-0.009 \\
(0.19)\end{array}$ & $\begin{array}{l}-0.012 \\
(0.26)\end{array}$ & $\begin{array}{l}0.059 \\
(1.14)\end{array}$ \\
\hline $\begin{array}{l}\text { Log of Initial per capita } \\
\text { Real GDP }\end{array}$ & $\begin{array}{l}-0.009 \\
(1.21)\end{array}$ & $\begin{array}{l}-0.007 \\
(0.94)\end{array}$ & $\begin{array}{l}-0.013 \\
(1.23)\end{array}$ & $\begin{array}{l}-0.020^{* *} \\
(1.97)\end{array}$ & $\begin{array}{l}-0.017 * \\
(1.77)\end{array}$ & $\begin{array}{l}-0.005 \\
(0.64)\end{array}$ & $\begin{array}{l}-0.014 \\
(1.39)\end{array}$ & $\begin{array}{l}-0.015 \\
(1.44)\end{array}$ & $\begin{array}{l}-0.021 * * \\
(2.03)\end{array}$ \\
\hline Exports to GDP & $\begin{array}{l}0.028 \\
(1.55)\end{array}$ & $\begin{array}{l}0.023 \\
(1.32)\end{array}$ & $\begin{array}{l}0.026 \\
(1.35)\end{array}$ & $\begin{array}{l}0.020 \\
(1.08)\end{array}$ & $\begin{array}{l}0.020 \\
(1.12)\end{array}$ & $\begin{array}{l}0.029 \\
(1.64)\end{array}$ & $\begin{array}{l}0.023 \\
(1.20)\end{array}$ & $\begin{array}{l}0.021 \\
(1.16)\end{array}$ & $\begin{array}{l}0.020 \\
(1.12)\end{array}$ \\
\hline Bank Loans to GDP & & $\begin{array}{l}-0.024 * * * \\
(3.06)\end{array}$ & & $\begin{array}{l}-0.030 * * \\
(2.33)\end{array}$ & $\begin{array}{l}-0.053^{* * *} \\
(4.84)\end{array}$ & & $\begin{array}{l}-0.014 \\
(1.26)\end{array}$ & & $\begin{array}{l}-0.029 * * \\
(2.20)\end{array}$ \\
\hline $\begin{array}{l}\text { Equity and Debt Issuance } \\
\text { to GDP }\end{array}$ & & $\begin{array}{l}0.411 * * * \\
(3.25)\end{array}$ & & $\begin{array}{l}0.462 * * * \\
(4.25)\end{array}$ & $\begin{array}{l}0.453^{* * * *} \\
(3.90)\end{array}$ & & & $\begin{array}{l}0.410 * * * \\
(4.42)\end{array}$ & $\begin{array}{l}0.448 * * * \\
(4.30)\end{array}$ \\
\hline Private Sector Presence & & & $\begin{array}{l}0.090^{* * *} \\
(4.07)\end{array}$ & $\begin{array}{l}0.069 * * * \\
(2.64)\end{array}$ & & & $\begin{array}{l}0.084^{* * * *} \\
(3.59)\end{array}$ & $\begin{array}{l}0.104 * * * \\
(4.97)\end{array}$ & $\begin{array}{l}0.070 * * * \\
(2.69)\end{array}$ \\
\hline Rule of law & & & $\begin{array}{l}0.007 \\
(1.40)\end{array}$ & $\begin{array}{l}0.012 * * \\
(2.15)\end{array}$ & $\begin{array}{l}0.015^{* *} \\
(2.54)\end{array}$ & & $\begin{array}{l}0.013^{* *} \\
(2.49)\end{array}$ & $\begin{array}{l}0.008^{*} \\
(1.83)\end{array}$ & $\begin{array}{l}0.012 * * \\
(2.09)\end{array}$ \\
\hline Property Rights & & & $\begin{array}{l}0.009 * * \\
(2.15)\end{array}$ & $\begin{array}{l}0.015^{* * * *} \\
(2.99)\end{array}$ & $\begin{array}{l}0.023 * * * \\
(5.08)\end{array}$ & & & & $\begin{array}{l}0.014 * * * \\
(2.69)\end{array}$ \\
\hline Relative Pluralism & & & & & & $\begin{array}{l}0.052 * \\
(1.94)\end{array}$ & $\begin{array}{l}0.043^{*} \\
(1.74)\end{array}$ & $\begin{array}{l}0.038^{*} \\
(1.69)\end{array}$ & $\begin{array}{l}0.025 \\
(0.95)\end{array}$ \\
\hline $\mathrm{N}$ & 515 & 510 & 510 & 505 & 506 & 515 & 509 & 514 & 505 \\
\hline $\mathrm{R}^{2}$ & 0.080 & 0.110 & 0.140 & 0.170 & 0.150 & 0.090 & 0.140 & 0.160 & 0.170 \\
\hline Adj $R^{2}$ & 0.076 & 0.102 & 0.127 & 0.154 & 0.139 & 0.082 & 0.129 & 0.147 & 0.154 \\
\hline F-statistic & 16.496 & 13.784 & 14.999 & 14.876 & 15.999 & 15.130 & 15.408 & 16.249 & 14.252 \\
\hline
\end{tabular}


Table 4 Blundell Bond dynamic panel data estimations of real capita GDP growth (annual data), two-step system GMM results

Table 4 presents the Blundell Bond two-step system GMM results based on the annual data. The dependent variable is real per capita GDP growth, and we include log of initial per capita real GDP, export to GDP, and secondary school enrollment rate as the base variables in the regressions. Definitions of variables are same as in Table 1 . N refers to number of observations included in the estimation. Specification statistics including Wald Chi ${ }^{2}$, P-value of Hansen over-identification test, AR(1) and AR(2) test of the error terms are also reported. Absolute values of t-statistics of the coefficients of the independent variables are reported in parentheses. $*, * *, * * *$ indicate significance levels of $10 \%, 5 \%$, and $1 \%$, respectively.

\begin{tabular}{|c|c|c|c|c|c|c|c|c|c|}
\hline & 1 & 2 & 3 & 4 & 5 & 6 & 7 & 8 & 9 \\
\hline Constant & $\begin{array}{l}-0.110 * * * \\
(19.11)\end{array}$ & $\begin{array}{l}-0.103 * * * \\
(6.32)\end{array}$ & $\begin{array}{l}0.013 \\
(0.17)\end{array}$ & $\begin{array}{l}0.086 \\
(0.86)\end{array}$ & $\begin{array}{l}0.127 \\
(1.32)\end{array}$ & $\begin{array}{l}-0.172 * * * \\
(10.00)\end{array}$ & $\begin{array}{l}0.050 \\
(0.43)\end{array}$ & $\begin{array}{l}-0.020 \\
(0.34)\end{array}$ & $\begin{array}{l}0.104 \\
(0.94)\end{array}$ \\
\hline $\begin{array}{l}\text { Log of Initial per capita } \\
\text { Real GDP }\end{array}$ & $\begin{array}{l}-0.018 * * * \\
(12.45)\end{array}$ & $\begin{array}{l}-0.019 * * * \\
(3.83)\end{array}$ & $\begin{array}{l}-0.012 \\
(0.67)\end{array}$ & $\begin{array}{l}-0.020 \\
(0.93)\end{array}$ & $\begin{array}{l}-0.022 \\
(1.15)\end{array}$ & $\begin{array}{l}-0.016^{* * *} \\
(3.14)\end{array}$ & $\begin{array}{l}-0.032 \\
(1.14)\end{array}$ & $\begin{array}{l}-0.015 \\
(0.94)\end{array}$ & $\begin{array}{l}-0.034 \\
(1.40)\end{array}$ \\
\hline Exports to GDP & $\begin{array}{l}0.015 * * * \\
(2.71)\end{array}$ & $\begin{array}{l}0.007 \\
(0.17)\end{array}$ & $\begin{array}{l}0.026 \\
(0.57)\end{array}$ & $\begin{array}{l}0.041 \\
(0.54)\end{array}$ & $\begin{array}{l}0.003 \\
(0.09)\end{array}$ & $\begin{array}{l}0.007 \\
(0.52)\end{array}$ & $\begin{array}{l}0.005 \\
(0.05)\end{array}$ & $\begin{array}{l}0.001 \\
(0.02)\end{array}$ & $\begin{array}{l}0.049 \\
(0.36)\end{array}$ \\
\hline Bank loans to GDP & & $\begin{array}{l}-0.036^{* * * *} \\
(3.27)\end{array}$ & & $\begin{array}{l}-0.033 \\
(1.07)\end{array}$ & $\begin{array}{l}-0.054^{*} \\
(1.93)\end{array}$ & & $\begin{array}{l}-0.031 * \\
(1.81)\end{array}$ & & $\begin{array}{l}-0.011 \\
(0.35)\end{array}$ \\
\hline $\begin{array}{l}\text { Equity and debt issuance } \\
\text { to GDP }\end{array}$ & & $\begin{array}{l}0.431 * * * \\
(5.06)\end{array}$ & & $\begin{array}{l}0.575^{* * *} \\
(3.90)\end{array}$ & $\begin{array}{l}0.520 * * * \\
(3.87)\end{array}$ & & & $\begin{array}{l}0.485^{* * * *} \\
(4.77)\end{array}$ & $\begin{array}{l}0.562^{* * *} \\
(3.87)\end{array}$ \\
\hline Private sector presence & & & $\begin{array}{l}0.094 * * \\
(2.36)\end{array}$ & $\begin{array}{l}0.105^{*} \\
(1.92)\end{array}$ & & & $\begin{array}{l}0.121^{* *} \\
(2.46)\end{array}$ & $\begin{array}{l}0.124^{* * *} \\
(3.37)\end{array}$ & $\begin{array}{l}0.121^{* *} \\
(2.20)\end{array}$ \\
\hline Rule of law & & & $\begin{array}{l}0.005 * * \\
(2.07)\end{array}$ & $\begin{array}{l}0.007 \\
(0.33)\end{array}$ & $\begin{array}{l}0.013^{*} \\
(1.65)\end{array}$ & & $\begin{array}{l}0.018 * \\
(1.92)\end{array}$ & $\begin{array}{l}0.006^{*} \\
(1.82)\end{array}$ & $\begin{array}{l}0.001 * \\
(1.71)\end{array}$ \\
\hline Property rights & & & $\begin{array}{l}0.009 * * * \\
(3.96)\end{array}$ & $\begin{array}{l}0.016 * * * \\
(2.65)\end{array}$ & $\begin{array}{l}0.026^{* * *} \\
(3.05)\end{array}$ & & & & $\begin{array}{l}0.011 \\
(1.00)\end{array}$ \\
\hline Relative pluralism & & & & & & $\begin{array}{l}0.057 * * * \\
(6.73)\end{array}$ & $\begin{array}{l}0.063^{* * *} \\
(3.49)\end{array}$ & $\begin{array}{l}0.038^{*} \\
(1.66) \\
\end{array}$ & $\begin{array}{l}0.013 * \\
(1.65) \\
\end{array}$ \\
\hline $\mathrm{N}$ & 515 & 510 & 510 & 505 & 506 & 515 & 509 & 514 & 505 \\
\hline Wald $\mathrm{Chi}^{2}$ & 1372.116 & 758.820 & 1324.109 & 420.866 & 387.587 & 3825.326 & 380.410 & 1064.103 & 266.648 \\
\hline P-value of Hansen test & 0.999 & 1.000 & 1.000 & 1.000 & 1.000 & 1.000 & 1.000 & 1.000 & 1.000 \\
\hline P-value of AR(1) test & 0.000 & 0.000 & 0.000 & 0.000 & 0.000 & 0.000 & 0.000 & 0.000 & 0.000 \\
\hline P-value of $\mathrm{AR}(2)$ test & 0.223 & 0.651 & 0.233 & 0.719 & 0.927 & 0.129 & 0.322 & 0.084 & 0.537 \\
\hline
\end{tabular}


Table 5 Blundell Bond dynamic panel data estimations of real capita GDP growth (three-year average), two-step system GMM results

Table 5 presents the Blundell Bond two-step system GMM results based on the three-year average growth. The dependent variable is the three-year (non-overlapping) average of real per capita GDP growth, and all independent variables are the initial year of the three year period. Based on our panel sample of 1986-2003, there are six time periods (the last is for just two years). We include log of initial per capita real GDP, export to GDP, and secondary school enrollment rate as the base variables in the regressions. Definitions of variables are same as in Table 1 . N refers to number of observations included in the estimation. Specification statistics including Wald Chi ${ }^{2}$, P-value of Hansen over-identification test, AR(1) and AR(2) test of the error terms are also reported. Absolute values of t-statistics of the coefficients of the independent variables are reported in parentheses. *, **, *** indicate significance levels of $10 \%, 5 \%$, and $1 \%$, respectively.

\begin{tabular}{|c|c|c|c|c|c|c|c|c|c|}
\hline & 1 & 2 & 3 & 4 & 5 & 6 & 7 & 8 & 9 \\
\hline Constant & $\begin{array}{l}0.027 \\
(1.16)\end{array}$ & $\begin{array}{l}-0.005 \\
(0.44)\end{array}$ & $\begin{array}{l}0.172 * * * \\
(6.12)\end{array}$ & $\begin{array}{l}0.151 * * * \\
(4.53)\end{array}$ & $\begin{array}{l}0.163 * * * \\
(5.36)\end{array}$ & $\begin{array}{l}-0.100 * * * \\
(7.04)\end{array}$ & $\begin{array}{l}0.051^{*} \\
(1.96)\end{array}$ & $\begin{array}{l}0.054 * * \\
(2.18)\end{array}$ & $\begin{array}{l}0.070 \\
(1.15)\end{array}$ \\
\hline $\begin{array}{l}\text { Log of Initial per capita } \\
\text { Real GDP }\end{array}$ & $\begin{array}{l}-0.016^{* * *} \\
(3.98)\end{array}$ & $\begin{array}{l}-0.009 * * * \\
(3.35)\end{array}$ & $\begin{array}{l}-0.043^{* * * *} \\
(8.69)\end{array}$ & $\begin{array}{l}-0.038 * * * \\
(4.42)\end{array}$ & $\begin{array}{l}-0.035 * * * \\
(5.87)\end{array}$ & $\begin{array}{l}-0.019 * * * \\
(9.20)\end{array}$ & $\begin{array}{l}-0.052 * * * \\
(6.62)\end{array}$ & $\begin{array}{l}-0.051 * * * \\
(7.56)\end{array}$ & $\begin{array}{l}-0.039 * * * \\
(2.82)\end{array}$ \\
\hline Exports to GDP & $\begin{array}{l}0.100 * * * \\
(12.85)\end{array}$ & $\begin{array}{l}0.059 * * * \\
(7.72)\end{array}$ & $\begin{array}{l}0.080 * * * \\
(5.09)\end{array}$ & $\begin{array}{l}0.043 * * \\
(2.05)\end{array}$ & $\begin{array}{l}0.046^{* *} \\
(2.54)\end{array}$ & $\begin{array}{l}0.057 * * * \\
(17.16)\end{array}$ & $\begin{array}{l}0.060 * * * \\
(3.78)\end{array}$ & $\begin{array}{l}0.056^{* * * *} \\
(3.44)\end{array}$ & $\begin{array}{l}0.057 * * \\
(2.45)\end{array}$ \\
\hline $\begin{array}{c}\text { Secondary school } \\
\text { Enrollment rate }\end{array}$ & $\begin{array}{l}0.177 * * * \\
(8.54)\end{array}$ & $\begin{array}{l}0.161 * * * \\
(8.86)\end{array}$ & $\begin{array}{l}0.217 * * * \\
(16.55)\end{array}$ & $\begin{array}{l}0.196 * * * \\
(5.34)\end{array}$ & $\begin{array}{l}0.194 * * * \\
(6.55)\end{array}$ & $\begin{array}{l}0.213 * * * \\
(23.06)\end{array}$ & $\begin{array}{l}0.268 * * * \\
(8.80)\end{array}$ & $\begin{array}{l}0.242 * * * \\
(11.40)\end{array}$ & $\begin{array}{l}0.212 * * * \\
(5.05)\end{array}$ \\
\hline Bank loans to GDP & & $\begin{array}{l}-0.004 \\
(1.42)\end{array}$ & & $\begin{array}{l}-0.015 \\
(1.19)\end{array}$ & $\begin{array}{l}-0.031^{*} \\
(1.90)\end{array}$ & & $\begin{array}{l}-0.014 \\
(1.27)\end{array}$ & & $\begin{array}{l}-0.013 \\
(1.07)\end{array}$ \\
\hline $\begin{array}{l}\text { Equity and debt issuance } \\
\text { to GDP }\end{array}$ & & $\begin{array}{l}0.245^{* * * *} \\
(8.67)\end{array}$ & & $\begin{array}{l}0.306^{* * * *} \\
(2.79)\end{array}$ & $\begin{array}{l}0.324 * * * \\
(3.26)\end{array}$ & & & $\begin{array}{l}0.296^{* * * *} \\
(3.79)\end{array}$ & $\begin{array}{l}0.401 * * * \\
(3.74)\end{array}$ \\
\hline Private sector presence & & & $\begin{array}{l}0.021 * * \\
(2.28)\end{array}$ & $\begin{array}{l}0.057 * * \\
(2.31)\end{array}$ & & & $\begin{array}{l}0.087 * * * \\
(5.21)\end{array}$ & $\begin{array}{l}0.102 * * * \\
(4.71)\end{array}$ & $\begin{array}{l}0.075 * * * \\
(4.00)\end{array}$ \\
\hline Rule of law & & & $\begin{array}{l}0.005^{* *} \\
(1.98)\end{array}$ & $\begin{array}{l}0.010^{* * *} \\
(2.59)\end{array}$ & $\begin{array}{l}0.011 * * \\
(2.04)\end{array}$ & & $\begin{array}{l}0.009 * * * \\
(2.87)\end{array}$ & $\begin{array}{l}0.012 * * * \\
(4.48)\end{array}$ & $\begin{array}{l}0.003^{*} \\
(1.69)\end{array}$ \\
\hline Property rights & & & $\begin{array}{l}0.021 * * * \\
(6.23)\end{array}$ & $\begin{array}{l}0.014 * * * \\
(2.85)\end{array}$ & $\begin{array}{l}0.021 * * * \\
(9.04)\end{array}$ & & & & $\begin{array}{l}0.009 * \\
(1.72)\end{array}$ \\
\hline Relative pluralism & & & & & & $\begin{array}{l}0.120 * * * \\
(18.33)\end{array}$ & $\begin{array}{l}0.115^{* * *} \\
(4.40)\end{array}$ & $\begin{array}{l}0.123 * * * \\
(6.17)\end{array}$ & $\begin{array}{l}0.048 * * \\
(2.35)\end{array}$ \\
\hline $\mathrm{N}$ & 181 & 179 & 179 & 177 & 177 & 181 & 179 & 181 & 177 \\
\hline Wald $\mathrm{Chi}^{2}$ & 417.995 & 972.015 & 1337.514 & 234.945 & 874.865 & 4198.352 & 978.204 & 711.839 & 891.463 \\
\hline P-value of Hansen test & 0.069 & 0.976 & 1.000 & 1.000 & 1.000 & 0.283 & 1.000 & 1.000 & 1.000 \\
\hline P-value of AR(1) test & 0.000 & 0.001 & 0.000 & 0.000 & 0.000 & 0.000 & 0.000 & 0.000 & 0.000 \\
\hline P-value of AR(2) test & 0.092 & 0.243 & 0.222 & 0.300 & 0.271 & 0.141 & 0.150 & 0.158 & 0.333 \\
\hline
\end{tabular}

